DOI: $10.19195 / 0137-1134.106 .23$

\title{
POMOC FINANSOWA PODMIOTÓW PRYWATNYCH UDZIELANA JEDNOSTKOM W STANACH NADZWYCZAJNYCH
}

\section{WSTĘP}

Uszczegółowiając tematykę pomocy finansowej (rozumianej jako pomoc pieniężna i niepieniężna) podmiotów prywatnych (zróżnicowanych z uwagi na kryterium formy organizacyjno-prawnej — osoby fizyczne; osoby prawne; jednostki organizacyjne nieposiadające osobowości prawnej, którym odrębna ustawa przyznaje zdolność prawną) oferowanej jednostkom w stanach nadzwyczajnych, chciałabym skupić swoją uwagę na prawnie dopuszczalnej i zorganizowanej formie takiej pomocy osadzonej w przepisach ustawy z dnia 14 marca 2014 r. o zasadach prowadzenia zbiórek publicznych ${ }^{1}$. Rozważania prowadzone nad obecnym kształtem prawodawstwa pozwalają na sformułowanie tezy o braku wyspecyfikowanej regulacji o charakterze szczególnym, która w całości odnosiłaby się wyłącznie do prezentowanego ogólnego zagadnienia pomocy finansowej podmiotów prywatnych udzielanej jednostkom w stanach nadzwyczajnych. Konsekwencja w postaci wielości możliwych do wyróżnienia różnorakich form pomocy uniemożliwia ich wyczerpującą analizę w ramach niniejszego opracowania.

Można pokusić się o wyrażenie stanowiska, że aksjologia leżąca u podstaw zbiórki publicznej wpisuje się w szerszą perspektywę badawczą dotyczącą społeczeństwa obywatelskiego. Zdaniem J. Blicharz niezbędne do zrozumienia istoty społeczeństwa obywatelskiego jest wprowadzenie dywersyfikacji między przesłaniem społeczeństwa obywatelskiego a instytucją społeczeństwa obywatelskiego. Autorka wprost wskazuje, że

sednem przesłania społeczeństwa obywatelskiego jest teza, że w warunkach istniejącego porządku obywatele zrzeszają się w celu realizacji różnych zadań na rzecz zarówno jednostkowego, jak i wspólnego dobra. W świetle tego założenia zbiorowość ludzka, której członkowie są obywatelami, podejmuje aktywne uczestnictwo w sferze publicznej bądź podejmuje w tym kierunku odpowiednie

\footnotetext{
${ }^{1}$ Dz.U. poz. 498 (dalej: ustawa o z.p.z.p.).
} 
starania. Można powiedzieć, że idea społeczeństwa obywatelskiego wyraża się w funkcjonowaniu różnych grup interesów, które cechuje określony stopień akceptacji wspólnej płaszczyzny zachowań i wartości. Cele i aspiracje określonych grup interesów pomagają kształtować kulturę instytucji, a wymogi instytucjonalne mają wpływ na interpretację i urzeczywistnienie określonych celów ${ }^{2}$.

Z kolei przedstawianie społeczeństwa obywatelskiego w wymiarze instytucjonalnym $-\mathrm{z}$ jednej strony — związane jest $\mathrm{z}$ nadaniem jednostkom określonych praw obywatelskich, politycznych i społecznych $-\mathrm{z}$ drugiej zaś $-\mathrm{z}$ istnieniem „różnorodnych form organizacji działających na zasadzie dobrowolności oraz reprezentujących odmienne interesy"3.

Nie wnikając szczegółowo w analizę regulacji prawnej odnoszącej się do stanów nadzwyczajnych, należy mimo wszystko wskazać, że ustrojodawca w przepisie art. 228 ust. 1 Konstytucji RP ${ }^{4}$ - objął pojęciem „stany nadzwyczajne" trzy jego rodzaje, tj. stan wojenny, stan wyjątkowy oraz stan klęski żywiołowej. Legalność wprowadzenia w życie każdego z nich jest implikowana koniecznością uchwalenia odrębnej ustawy, a na jej podstawie rozporządzenia, które podlega dodatkowemu podaniu do publicznej wiadomości. Wspomnianymi ustawami są: ustawa $\mathrm{z}$ dnia 21 czerwca 2002 r. o stanie wyjątkowym ${ }^{5}$, ustawa z dnia 18 kwietnia 2002 r. o stanie klęski żywiołowej ${ }^{6}$ oraz ustawa z dnia 29 sierpnia 2002 r. o stanie wojennym oraz o kompetencjach Naczelnego Dowódcy Sił Zbrojnych i zasadach jego podległości konstytucyjnym organom Rzeczypospolitej Polskiej ${ }^{7}$

\section{ZBIÓRKA PUBLICZNA — DELIMITACJA POJĘCIA}

Od dnia 18 lipca 2014 r. funkcjonują w przestrzeni prawnej nowe zasady prowadzenia zbiórek publicznych. Ustawa o zasadach prowadzenia zbiórek publicznych uchyliła obowiązywanie ustawy z dnia 15 marca 1933 r. o zbiórkach publicznych ${ }^{8}$. Omawiana ustawa zrewolucjonizowała system prowadzenia zbió-

2 J. Blicharz, Przesłanie a instytucjonalność spoleczeństwa obywatelskiego. Relacje sektora obywatelskiego z państwem i sektorem gospodarczym, [w:] Prawna działalność instytucji społeczeństwa obywatelskiego, red. J. Blicharz, J. Boć, Wrocław 2009, s. 107.

3 Ibidem. Na temat pojęcia społeczeństwa obywatelskiego - zob. M. Jabłoński, Społeczeństwo obywatelskie - dylematy konstytucyjnoprawne, [w:] Prawna działalność instytucji spoteczeństwa obywatelskiego, s. 23-31; L. Olszewski, Rozwój gospodarczy a społeczeństwo obywatelskie, [w:] Prawna działalność instytucji społeczeństwa obywatelskiego, s. 201-211; B. Olszewski, Wolontariat jako forma realizacji idei społeczeństwa obywatelskiego, [w:] Prawna działalność instytucji społeczeństwa obywatelskiego, s. 649-659.

4 Dz.U. Nr 78, poz. 483, z późn. zm.

5 Tekst jedn. Dz.U. z 2016 r., poz. 886.

6 Tekst jedn. Dz.U. z 2014 r., poz. 333 z późn. zm. (dalej: ustawa o s.k.ż.).

7 Tekst jedn. Dz.U. z 2016 r., poz. 851 (dalej: ustawa o s.w.).

8 Tekst jedn. Dz.U. 2013 r., poz. 732 (dalej: ustawa o z.p.). 
rek publicznych. Zasadnicza zmiana polega na wprowadzeniu w miejsce obowiązku uprzedniego uzyskania pozwolenia władzy ${ }^{9}$ (tj. wójta, burmistrza, prezydenta miasta bądź starosty lub marszałka województwa bądź ministra właściwego do spraw administracji publicznej ${ }^{10}$ ) obowiązek zgłoszenia przez organizatora zbiórki i zamieszczenia informacji o zgłoszeniu przez ministra właściwego do spraw administracji publicznej na ogólnopolskim elektronicznym portalu zbiórek publicznych (art. 5 ust. 1 ustawy o z.p.z.p.).

Dokonując wykładni literalnej pojęcia „zbiórka publiczna”, zawartego w przepisie art. 1 ust. 1 ustawy o z.p.z.p. ${ }^{11}$, uznaję, że struktura tego pojęcia ma charakter trójelementowy. $Z$ uwagi na kryterium przedmiotowe - zbiórką publiczną jest wyłącznie zbieranie ofiar w gotówce lub w naturze ${ }^{12}$. Zbiórka publiczna nie może być przeprowadzona $\mathrm{w}$ celu prawnie relewantnym - ten aspekt został $\mathrm{w}$ miarę precyzyjnie dookreślony przez ustawodawcę. Skonkretyzowanie celu nastąpiło w dwojaki sposób ${ }^{13}$. W świetle wskazanego przepisu celem zbiórki publicznej jest albo cel pozostający w sferze zadań publicznych, o których mowa w przepisie art. 4 ust. 1 ustawy z dnia 24 kwietnia 2003 r. o działalności pożytku publicz-

9 Zob. art. 1 ustawy o z.p.

10 Zob. art. 2 ust. 1 ustawy o z.p.

11 Ustawodawca posługuje się pojęciem „zbiórka publiczna” na gruncie innych aktów prawnych, takich jak: ustawa z dnia 27 czerwca 1997 r. o partiach politycznych (Dz.U. z 2011 r. Nr 155, poz. 924, tekst jedn. z późn. zm.) - art. 24 ust. 6 „Partia polityczna nie może przeprowadzać zbiórek publicznych"; ustawa z dnia 5 stycznia 2011 r. — Kodeks wyborczy (Dz.U. Nr 21, poz. 112, tekst jedn. z późn. zm.) — art. $131 \S 2$,Zabronione jest przeprowadzanie przez komitet wyborczy zbiórek publicznych"; ustawa z dnia 24 czerwca 1999 r. o wykonywaniu inicjatywy ustawodawczej przez obywateli (Dz.U. Nr 62, poz. 688, z późn. zm.) — art. 15 ust. 2 „Komitet może organizować zbiórki publiczne środków finansowych na cele związane z wykonywaniem inicjatywy ustawodawczej, na zasadach i w trybie określonych w ustawie z dnia 14 marca 2014 r. o zasadach prowadzenia zbiórek publicznych"; ustawa z dnia 17 maja 1989 r. o gwarancjach wolności sumienia i wyznania (Dz.U. z 2005 r. Nr 231, poz. 1965, tekst jedn. z późn. zm.) - art. 24 ust. 2 pkt 3 „Środki na realizację działalności charytatywno-opiekuńczej pochodzą w szczególności z: [...] dochodów z imprez i zbiórek publicznych”. Zob. J. Niczyporuk, Zbiórki publiczne, „Studia Iuridica Lublinensia” 2007, nr 10, s. 31-32.

12 Na gruncie ustawy o zbiórkach publicznych również była mowa o zbieraniu ofiar w gotówce lub w naturze - zob. art. 1 ustawy o z.p.

13 W porównaniu z wcześniejszą regulacją nastąpiła zmiana w sposobie ustalenia celu zbiórki. Organ, wydając pozwolenie na zbiórkę publiczną, był obowiązany zważyć cel zbiórki przez pryzmat tego, czy nie jest przeciwny prawu i czy jest godny poparcia ze stanowiska interesu publicznego przy czym decyzja taka miała przymiot decyzji uznaniowej, albowiem organ dysponował możliwością wyboru skutku prawnego - tak Wojewódzki Sąd Administracyjny w Warszawie w wyroku z dnia 20 października 2005 r., sygn. akt IV SA/Wa 1347/05; oraz Naczelny Sąd Administracyjny w wyroku z dnia 29 listopada 2005 r., sygn. akt I OSK 176/05. Za takie cele uznawano w szczególności: cele religijne, państwowe, oświatowe, zdrowotne, kulturalno-społeczne i społeczno-opiekuńcze — zob. art. 3 ust. 2 ustawy o z.p. 
nego i o wolontariacie ${ }^{14}$, albo cel religijny ${ }^{15}$. Dopuszczalność zakwalifikowania zbierania ofiar $\mathrm{w}$ gotówce lub $\mathrm{w}$ naturze jako zbiórki publicznej jest uzależniona od zogniskowania tych czynności w ściśle określonym miejscu, tj. w miejscu publicznym (miejscu ogólnodostępnym). Przykładowo (o czym świadczy posłużenie się przez ustawodawcę sformułowaniem „w szczególności”) zaliczono do niego ulice, place, parki i cmentarze ${ }^{16}$. Wobec braku definicji pojęcia „miejsce publiczne" posiłkowo można sięgnąć do judykatury Sądu Najwyższego. Twórcy nowej ustawy wprost optują za skorzystaniem z poglądu wyrażonego w wyroku z dnia 9 listopada 1971 r. ${ }^{17}$, w którym Sąd Najwyższy zrównał miejsce publiczne z każdym miejscem dostępnym dla nieokreślonej liczby osób ${ }^{18}$. W poprzednim stanie prawnym była mowa o publicznym zbieraniu ofiar w gotówce lub naturze. W zasadzie od początku obowiązywania ustawy o zbiórkach publicznych można mówić o ukształtowaniu poglądu o braku podstaw do semantycznego zrównania publicznego zbierania ofiar ze zbieraniem ofiar w miejscach publicznych. Sposób zbierania ofiar w postaci odwiedzania mieszkań prywatnych „i dostępność w ten sposób do nieokreślonej liczby osób z prośbą o ofiary" odpowiada zakresowo pojęciu publicznego zbierania ofiar ${ }^{19}$. Naczelny Sąd Administracyjny na kanwie przepisów ustawy o zbiórkach publicznych wyjaśnił, że

istota publicznego zbierania ofiar polega na zbieraniu jawnie ofiar od osób innych [...] przy czym grono tych osób nie jest z góry zamknięte, ale zależy od możliwości dotarcia do nich przez organizatora zbiórki. Przymiotnik ,publiczne” wskazuje przede wszystkim, że zbiórka odbywa się wobec świadków, w miejscu dostępnym dla wszystkich, oficjalnie i jawnie ${ }^{20}$.

14 Dz.U. z 2016 r., poz. 239, tekst jedn. z późn. zm. (dalej: ustawa o d.p.p.w.). Jest to wyliczenie zadań publicznych o charakterze zamkniętym. Poglądu tego nie przekreśla możliwość wprowadzenia dodatkowych zadań w drodze rozporządzenia Rady Ministrów (delegacja została zawarta w przepisie art. 4 ust. 2 ustawy o d.p.p.w.) - zob. J. Blicharz [w:] J. Blicharz, A. Huchla, Ustawa o działalności pożytku publicznego i o wolontariacie. Komentarz, Warszawa 2008, s. 54. Co ważne, jak dotąd takie rozporządzenie nie zostało wydane.

15 Miejsce zbierania ofiar w gotówce lub w naturze na cele religijne determinuje możliwość kwalifikacji, czy takie czynności są normatywnie określoną zbiórką publiczną. Interpretacja a contrario przepisu art. 2 pkt 1 ustawy o z.p.z.p. pozwala na takie stwierdzenie. Utrzymana jest w tym zakresie ciągłość regulacji, gdyż zarówno w przywołanym przepisie, jak i w przepisie art. 13 ust. 1 ustawy o z.p. uznano, że zbiórką publiczną nie jest, czy też ustawa o zbiórkach publicznych nie ma zastosowania do zbierania ofiar „na cele religijne, kościelną działalność charytatywno-opiekuńczą, naukową, oświatową i wychowawczą oraz na utrzymanie duchownych i członków zakonów, jeżeli odbywa w obrębie terenów kościelnych, kaplic oraz w miejscach i okolicznościach zwyczajowo przyjętych w danej okolicy i w sposób tradycyjnie ustalony".

${ }_{16}$ Zob. art. 1 ust. 2 ustawy o z.p.z.p.

17 Sygn. akt V KRN 219/71.

18 Na temat pojęcia „miejsca publicznego” zob. J. Blicharz, Ustawa o zasadach prowadzenia zbiórek publicznych. Komentarz, Wrocław 2015, s. 35-37.

19 Wyrok Sądu Najwyższego z dnia 3 listopada 1936 r., sygn. akt III K 1371/36.

20 Wyrok Naczelnego Sądu Administracyjnego z dnia 14 lutego 2013 r., sygn. akt I OSK 2613/12. 
Zbiórką publiczną nie będzie zatem zbieranie ofiar w gotówce lub w naturze między innymi wśród grona osób znajomych osobiście przeprowadzających zbiórkę (art. 2 pkt 3 ustawy o z.p.z.p.); wśród młodzieży szkolnej na terenach szkolnych, odbywające się na podstawie pozwolenia władz szkolnych (art. 2 pkt 4 ustawy o z.p.z.p.) oraz w ramach zbiórek koleżeńskich odbywających się w lokalu urzędu publicznego na podstawie pozwolenia kierownika urzędu lub innym zakładzie pracy (art. 2 pkt 5 ustawy o z.p.z.p.). Nie jest to nowe rozwiązanie normatywne, gdyż jest ściśle treściowo skorelowane $\mathrm{z}$ regulacją zawartą $\mathrm{w}$ przepisie art. 13 ustawy o z.p.

Wśród zadań publicznych, wymienionych w licznym katalogu we wspomnianym już przepisie art. 4 ust. 1 ustawy o d.p.p.w., warto wyeksponować zadanie z zakresu pomocy ofiarom katastrof, klęsk żywiołowych, konfliktów zbrojnych i wojen w kraju i za granicą (art. 4 ust. 1 pkt 24 ustawy o d.p.p.w.). Odwołując się do pojęcia stanu nadzwyczajnego - dla jasności wywodów - należy w tym miejscu wyjaśnić konotację pojęć czy też okoliczności, których zaistnienie uzasadnia wprowadzenie poszczególnych stanów nadzwyczajnych. Prezydent Rzeczypospolitej na wniosek Rady Ministrów, zgodnie z przepisem art. 229 Konstytucji RP, może wprowadzić stan wojenny na części albo na całym terytorium państwa w sytuacji zewnętrznego zagrożenia państwa, zbrojnej napaści na terytorium Rzeczypospolitej Polskiej lub gdy z umowy międzynarodowej wynika zobowiązanie do wspólnej obrony przeciwko agresji. Organem, który jest umocowany do wprowadzenia stanu wyjątkowego - podobnie jak w przypadku stanu wojennego jest Prezydent Rzeczypospolitej podejmujący decyzję na wniosek Rady Ministrów. Pozytywną przesłanką wprowadzenia stanu wyjątkowego jest zagrożenie konstytucyjnego ustroju państwa, bezpieczeństwa obywateli lub porządku publicznego (art. 230 Konstytucji RP). Natomiast stan klęski żywiołowej może być wprowadzony przez Radę Ministrów na części albo na całym terytorium Rzeczypospolitej Polskiej w celu zapobieżenia skutkom katastrof naturalnych lub awarii technicznych noszących znamiona klęski żywiołowej (art. 232 Konstytucji RP). Pojęcie klęski żywiołowej, mające charakter pojęcia zbiorczego, obejmuje swoim zakresem znaczeniowym zarówno katastrofę naturalną, jak i awarię techniczną,

których skutki zagrażają życiu lub zdrowiu dużej liczby osób, mieniu w wielkich rozmiarach albo środowisku na znacznych obszarach, a pomoc i ochrona mogą być skutecznie podjęte tylko przy zastosowaniu nadzwyczajnych środków, we współdziałaniu różnych organów i instytucji oraz specjalistycznych służb i formacji działających pod jednolitym kierownictwem²1.

Wobec tego, uznając rygoryzm sformułowania katalogu zadań publicznych zawartych w przepisie art. 4 ust. 1 ustawy o d.p.p.w., należy przyjąć, że zbiórka publiczna jako forma pomocy finansowej podmiotów prywatnych udzielanej jednostkom będzie właściwa czy też nawet dopuszczalna wyłącznie dla ofiar (jednostek), które ucierpiały w wyniku stanu klęski żywiołowej i stanu wojennego.

21 Art. 3 ust. 1 pkt 1 ustawy o s.k.ż. 
W świetle prezentowanych przepisów nie ma uzasadnionych podstaw do uznania, że instytucja zbiórki publicznej może być wykorzystana w celu udzielenia pomocy ofiarom stanu wyjątkowego. Może zatem budzić zdziwienie ulokowanie w ustawie o stanie wyjątkowym przepisu art. 16 ust. 3 o następującej treści:

Informacja o zgłoszeniu zbiórki publicznej, która ma być przeprowadzona na obszarze, na którym wprowadzono stan wyjątkowy, może zostać zamieszczona na ogólnopolskim elektronicznym portalu zbiórek publicznych, tylko wówczas, gdy w ocenie ministra właściwego do spraw administracji publicznej, przeprowadzenie zbiórki nie utrudni realizacji celów wprowadzenia stanu wyjątkowego ${ }^{22}$,

zwłaszcza wobec braku jakiegokolwiek wytłumaczenia ze strony normodawcy.

Omawiając zagadnienie zbiórek publicznych, należy pochylić się nad problematyką sposobów ich przeprowadzania. Ustawodawca w obecnie obowiązującym unormowaniu, nie wypowiada się wprost na ten temat. Wydaje się, że poprzez stosowanie wykładni historycznej uzasadnione jest chociażby posiłkowe nawiązanie do przepisów rozporządzenia Ministra Spraw Wewnętrznych i Administracji z dnia 6 listopada 2003 r. w sprawie sposobów przeprowadzania zbiórek publicznych oraz zakresu kontroli nad tymi zbiórkami ${ }^{23}$. W przepisie $\S 1$ rozporządzenia w sprawie s.p.z.p. wskazano bowiem, że dopuszczalnymi formami zbiórek publicznych ofiar w gotówce są: dobrowolne wpłaty na konto (założone osobno dla każdej zbiórki publicznej przez przeprowadzającego zbiórkę publiczną); zbieranie ofiar do puszek kwestarskich oraz skarbon stacjonarnych (umieszczanych w obiektach, za zgodą ich właścicieli lub użytkowników); sprzedaż cegiełek wartościowych; sprzedaż przedmiotów. $Z$ kolei zbieranie ofiar $\mathrm{w}$ gotówce zostało zawężone jedynie do przypadku, gdy wszystkie ofiary będą mogły być w niezmienionej postaci zużyte w założonym celu (§ 2 rozporządzenia w sprawie s.p.z.p.). Zaprezentowane sposoby przeprowadzania zbiórek publicznych mogły mieć miejsce poprzez domokrążne zbieranie ofiar, gdy organizator ,ze względu na teren, na którym zbiórka publiczna ma być przeprowadzona, lub ze względu na charakter zbiórki publicznej uzna to za społecznie uzasadnione, w szczególności gdy celem zbiórki publicznej jest pomoc ofiarom klęsk żywiołowych" (§ 4 rozporządzenia w sprawie s.p.z.p.). Co ważne, ustawodawca nie transponował identycznej regulacji do ustawy o zasadach prowadzenia zbiórek publicznych. Biorąc pod rozwagę dopuszczalność wykorzystywania na gruncie nowych przepisów tożsamych sposobów przeprowadzania zbiórki publicznej, należy przeanalizować treść rozporządzenia Ministra Administracji i Cyfryzacji z dnia 9 czerwca 2014 r. w sprawie wzorów dokumentów dotyczących zbiórek publicznych $^{24}$, a zwłaszcza wzór zgłoszenia zbiórki publicznej w zakresie danych dotyczących zbiórki publicznej, tj. sposobu przeprowadzenia zbiórki publicznej. Minister Administracji i Cyfryzacji, nie tworząc enumeratywnego katalogu spo-

$22 \mathrm{~W}$ zasadzie identyczna regulacja znajduje się w przepisie art. 22 ust. 3 ustawy o s.w. Brak podobnej bądź tożsamej regulacji w ustawie o stanie klęski żywiołowej.

23 Dz.U. Nr 199, poz. 1947 (dalej: rozporządzenie w sprawie s.p.z.p.).

24 Dz.U. poz. 833. 
sobów, lecz wyliczając je w formie otwartej — „np. zbiórka do puszek, skarbon itp." - pozostawił podmiotowi przeprowadzającemu zbiórkę swobodę w zakresie wyboru sposobu prowadzenia zbiórki publicznej. Powyższe ustalenia w części przekreśla definitywne uznanie w ustawie o zasadach prowadzenia zbiórek publicznych, że zbiórką publiczną jest wyłącznie zbieranie ofiar w gotówce lub w naturze.

Nawiązując do tych ustaleń, konieczne jest uściślenie relacji między powszechnie spotykanymi formami pomocy, jak: przelewy na konto bankowe, wpłaty na konto bankowe, SMS-y charytatywne oraz inne formy kwalifikowane do instytucji finansowania obywatelskiego (crowdfundingu), a zakresem pozytywnego zastosowania przepisów ustawy o zasadach prowadzenia zbiórek publicznych.

Warto w tym miejscu wprost zacytować fragment uzasadnienia do rządowego projektu ustawy o zasadach prowadzenia zbiórek publicznych z projektem aktu wykonawczego ${ }^{25}$ :

dodatkową regulację ofiar zbieranych w gotówce lub w naturze w miejscach publicznych uzasadnia fakt, że gotówka lub dary zbierane w wyżej opisany sposób nie są ewidencjonowane i nie pozostaje ślad przepływu tych ofiar, więc informacje o przekazanej gotówce i darach, a także o darczyńcy, są niedostępne dla organów kontroli skarbowej. Z perspektywy obywatela oznacza to też, że w razie pojawienia się problemów ciężko jest o dowód przekazania darowizny. W art. 1 określa się, że obowiązkiem zgłoszenia zbiórki i zamieszczenia sprawozdania z jej przeprowadzenia nie będą objęte formy zbierania ofiar, w których pozostawiony jest ślad przepływu środków pieniężnych i darów, gdzie ma miejsce ich ewidencjonowanie (przelewy na konta bankowe, wpłaty na konto online, przekazywanie darów za pomocą wirtualnych platform handlowych, wpłaty za pomocą SMS-ów, deklaracje wpłat na wszystkich formularzach związanych z systemem bankowym). Pozyskane w ten sposób środki są ewidencjonowane i dostępne dla organów kontroli, natomiast w interesie organizacji przeprowadzających zbiórki leży udostępnianie informacji odnośnie do sposobu spożytkowania zebranych środków. Zbiórką publiczną nie będzie też publikowanie w mediach, Internecie, wysyłanie za pomocą środków komunikacji elektronicznej (mailing, SMS-y) z wykorzystaniem bazy danych (w tym również zakupionej bazy danych) apeli o przekazywanie wpłat na konto, o złożenie zleceń stałych, przelewów na konto bankowe lub o przesłanie SMS-ów na określony numer ${ }^{26}$.

W literaturze przedmiotu zwraca się ponadto uwagę na aukcję na cele charytatywne - jako potencjalną formę pomocy — przeciwstawiając ją instytucji zbiórki publicznej27. W konsekwencji, wskazane przykładowe formy pomocy są poddane odmiennemu reżimowi prawnemu niż ustawa o zasadach prowadzenia zbiórek publicznych. Przykładowo ustawa z dnia 16 lipca 2004 r. - Prawo telekomunikacyjne ${ }^{28}$ jest aktem prawnym właściwym dla formy pomocy w postaci SMS-ów charytatywnych. Z kolei w stosunku do przelewów i wpłat na konto bankowe ma zastosowanie ustawa z dnia 23 kwietnia 1964 r. - Kodeks cywilny ${ }^{29}$

25 Druk 1726 (dalej: Uzasadnienie).

26 Uzasadnienie, s. 4.

27 S. Płażek [w:] Partycypacja obywateli i podmiotów obywatelskich $w$ podejmowaniu rozstrzygnięć publicznych na poziomie lokalnym, red. M.J. Mączyński, Warszawa 2012, s. 20.

28 Tekst jedn. Dz.U. z 2014 r., poz. 243 z późn. zm.

29 Tekst jedn. Dz.U. z 2016 r., poz. 380 z późn. zm. 
oraz ustawa z dnia 28 lipca 1983 r. o podatku od spadków i darowizn ${ }^{30}$. Mianem crowdfundingu określa się formę „finansowania realizacji przedsięwzięcia poprzez zmobilizowanie możliwie największej liczby osób do wnoszenia, często małych, wpłat. W zamian twórca projektu oferuje wspierającym unikalne bonusy (bilety, spotkania, gadżety), oferuje swoje produkty lub usługi bądź też oddaje udziały w swoim przedsięwzięciu" 31 .

\section{ORGANIZATOR ZBIÓRKI PUBLICZNEJ}

Pomoc finansową podmiotów prywatnych udzielaną jednostkom w stanach nadzwyczajnych przeprowadzoną $\mathrm{w}$ formie zbiórki publicznej można określić mianem pomocy pośredniej. Nie są to bowiem czynności podejmowane w sposób bezpośredni przez podmiot prywatny, lecz za pośrednictwem grupy podmiotów, zdefiniowanych przez ustawodawcę jako organizator zbiórki. Mianem tym określa się organizację pozarządową $\mathrm{w}$ rozumieniu art. 3 ust. 2 ustawy o d.p.p.w. ${ }^{32}$; podmiot, o którym mowa $\mathrm{w}$ art. 3 ust. 3 ustawy o d.p.p.w. ${ }^{33}$; komitet społeczny powołany w celu przeprowadzenia zbiórki publicznej ${ }^{34}$. Kategoryczna treść przepisu

30 Tekst jedn. Dz.U. z 2016 r., poz. 205 z późn. zm.

31 J. Blicharz, Ustawa o zasadach prowadzenia zbiórek publicznych, s. 40. Na temat crowdfundingu zob. więcej J.M. Karolczak, Opinia prawna dotyczaca rządowego projektu ustawy o zasadach prowadzenia zbiórek publicznych (druk nr 1726) z dnia 31 października $2013 \mathrm{r}$., http://orka. sejm.gov.pl/rexdomk7.nsf/Opdodr?OpenPage\&nr=1726, s. 7.

32 Organizacjami pozarządowymi, zgodnie z przywołanym przepisem, są: „1) niebędące jednostkami sektora finansów publicznych w rozumieniu ustawy z dnia 27 sierpnia 2009 r. o finansach publicznych lub przedsiębiorstwami, instytutami badawczymi, bankami i spółkami prawa handlowego będącymi państwowymi lub samorządowymi osobami prawnymi, 2) niedziałające w celu osiągnięcia zysku - osoby prawne lub jednostki organizacyjne nieposiadające osobowości prawnej, którym odrębna ustawa przyznaje zdolność prawną, w tym fundacje i stowarzyszenia, z zastrzeżeniem ust. 4”. Zob. J. Blicharz, Udziat polskich organizacji pozarządowych w wykonywaniu zadań administracji publicznej, Wrocław 2005.

33 Są to następujące podmioty „1) osoby prawne i jednostki organizacyjne działające na podstawie przepisów o stosunku Państwa do Kościoła Katolickiego w Rzeczypospolitej Polskiej, o stosunku Państwa do innych kościołów i związków wyznaniowych oraz o gwarancjach wolności sumienia i wyznania, jeżeli ich cele statutowe obejmują prowadzenie działalności pożytku publicznego; 2) stowarzyszenia jednostek samorządu terytorialnego; 3) spółdzielnie socjalne; 4) spółki akcyjne i spółki z ograniczoną odpowiedzialnością oraz kluby sportowe będące spółkami działającymi na podstawie przepisów ustawy z dnia 25 czerwca 2010 r. o sporcie, które nie działają w celu osiągnięcia zysku oraz przeznaczają całość dochodu na realizację celów statutowych oraz nie przeznaczają zysku do podziału między swoich udziałowców, akcjonariuszy i pracowników".

${ }^{34}$ Sposób powołania komitetu społecznego określa przepis art. 4 ustawy o z.p.z.p. Komitet społeczny jest powoływany przynajmniej przez „3 osoby fizyczne posiadające pełną zdolność do czynności prawnych oraz niekarane za popełnienie przestępstwa przeciwko wiarygodności dokumentów, mieniu, obrotowi gospodarczemu, obrotowi pieniędzmi i papierami wartościowymi lub za przestępstwo skarbowe" w formie aktu założycielskiego. 
art. 3 ustawy o z.p.z.p. pozwala na wyciągnięcie wniosku, że wyłącznie podmioty przedstawione w przywołanym katalogu są uprawnione do prowadzenia zbiórki publicznej. Takim podmiotem nie będzie osoba fizyczna, chyba że zorganizuje się z innymi osobami fizycznymi w komitet społeczny. Brak zatem oparcia w obowiązujących przepisach dla stwierdzenia, że sam podmiot prywatny nieposiadający statusu organizatora zbiórki mógłby ją zorganizować w sposób legalny.

Ustawa o zasadach prowadzenia zbiórek publicznych w sposób ewidentny rozszerzyła wykaz podmiotów uprawnionych do prowadzenia zbiórki publicznej. Pozwolenie na zbiórkę publiczną, niezbędne do jej prowadzenia na gruncie ustawy o zbiórkach publicznych, mogły uzyskać wyłącznie stowarzyszenia i organizacje posiadające osobowość prawną albo komitety organizowane dla przeprowadzenia określonego celu, który musiał być zgodny ze statutem stowarzyszenia lub organizacji bądź z aktem organizacyjnym komitetu (art. 4 ustawy o z.p.).

\section{ZASADY PROWADZENIA ZBIÓREK PUBLICZNYCH}

Nowa ustawa o zasadach prowadzenia zbiórek publicznych całkowicie zmieniła optykę odnoszoną do instytucji zbiórek publicznych. Ustawa o zbiórkach publicznych przez ponad osiemdziesiąt lat jej obowiązywania została poddana nowelizacji wyłącznie osiem razy ${ }^{35}$, co zrodziło potrzebę dostosowania instytucji zbiórki publicznej do nowej rzeczywistości, zwłaszcza powszechnej rzeczywistości internetowej. Ustawodawca złagodził reglamentacyjny reżim organizowania zbiórki publicznej przejawiający się przede wszystkim w zniesieniu obowiązku uzyskania pozwolenia, wyposażając jednocześnie ministra właściwego do spraw administracji publicznej w funkcję administratora portalu zbiórek publicznych (art. 5 ust. 3 ustawy o z.p.z.p.). Zmieniła się rola organów państwa w organizacji zbiórki publicznej, mimo wszystko pełnią one funkcję nadzorczą nad jej prawidłowym, zgodnym z prawem i rzetelnym przebiegiem. Oprócz akcentowanych powyżej różnic legislacyjnych należy zwrócić uwagę na obowiązek ciążący na

35 Dekret Prezydenta Rzeczypospolitej z dnia 19 listopada 1938 r. o rozciągnięciu mocy obowiązującej niektórych aktów ustawodawczych na odzyskane ziemie Śląska Cieszyńskiego (Dz.U. $\mathrm{Nr}$ 90, poz. 612); dekret z dnia 28 lipca 1948 r. w sprawie zmiany ustawy o zbiórkach publicznych (Dz.U. Nr 36, poz. 250); ustawa z dnia 20 maja 1971 r. przepisy wprowadzające Kodeks wykroczeń (Dz.U. Nr 12, poz. 115); ustawa z dnia 17 maja 1989 r. o stosunku Państwa do Kościoła katolickiego w Polskiej Rzeczypospolitej Ludowej (Dz.U. Nr 29, poz. 154); ustawa z dnia 17 maja 1990 r. o podziale zadań i kompetencji określonych w ustawach szczególnych pomiędzy organy gminy a organy administracji rządowej oraz o zmianie niektórych ustaw (Dz.U. Nr 34, poz. 198); ustawa z dnia 24 lipca 1998 r. o zmianie niektórych ustaw określających kompetencje organów administracji publicznej — w związku z reformą ustrojową państwa (Dz.U. Nr 106, poz. 668); ustawa z dnia 24 kwietnia 2003 r. Przepisy wprowadzające ustawę o działalności pożytku publicznego i o wolontariacie (Dz.U. Nr 96, poz. 874); ustawa z dnia 13 lipca 2012 r. o zmianie ustawy o działach administracji rządowej oraz niektórych innych ustaw (Dz.U. poz. 908). 
organizatorze zbiórki polegający na sporządzaniu i doręczaniu ministrowi właściwemu do spraw administracji publicznej dwóch sprawozdań, tj. sprawozdania z przeprowadzonej zbiórki publicznej oraz sprawozdania ze sposobu rozdysponowania zebranymi ofiarami (art. 16 ust. 1 ustawy o z.p.z.p.).

Zasady prowadzenia zbiórek publicznych charakteryzują się transparentnością regulacji w zakresie udostępniania danych dotyczących: numeru zbiórki, organizatora zbiórki (nazwa podmiotu, oznaczenie siedziby, numer wpisu do Krajowego Rejestru Sądowego, numer identyfikacji podatkowej (NIP) lub numer identyfikacyjny REGON; imiona i nazwiska oraz miejsca zamieszkania członków komitetu społecznego), celu zbiórki publicznej, sposobu prowadzenia zbiórki publicznej, miejsca prowadzenia zbiórki publicznej, terminu rozpoczęcia i zakończenia zbiórki publicznej, przewidywanych kosztów niezbędnych do zorganizowania i przeprowadzenia zbiórki publicznej, które zostaną pokryte z zebranych ofiar ${ }^{36}$. Ponadto organizator zbiórki obowiązany jest wyposażyć osoby, przeprowadzające zbiórkę publiczną $\mathrm{w}$ identyfikatory, które powinny zawierać określone dane identyfikacyjne: imię i nazwisko osoby przeprowadzającej zbiórkę publiczną oraz dodatkowo informacje o nazwie, celu zbiórki publicznej i jej organizatorze oraz numerze zbiórki publicznej (art. 8 ustawy o z.p.z.p.). Dzięki takim rozwiązaniom legislacyjnym podmiot prywatny, podejmując decyzję o chęci niesienia pomocy jednostkom poszkodowanym w stanach nadzwyczajnych, ma szansę pełnego zapoznania się z warunkami tej pomocy, a jego wybór ma znamiona wyboru świadomego. Przez okres dziesięciu lat (licząc od dnia upływu terminu przesłania ostatniego sprawozdania) może zapoznać się z informacją o zgłoszeniu zbiórki publicznej oraz ze sprawozdaniami (art. 19 ustawy o z.p.z.p.). Intencją twórców nowej ustawy o zbiórkach publicznych jest ułatwienie obywatelom realizacji ofiarności, zwiększenie obywatelskiej kontroli zbiórek, zwiększenie dostępu do danych (o których mowa powyżej) związanych z planowaną i zrealizowaną zbiórką. Podmiot prywatny, udzielając pomocy finansowej jednostkom w stanach nadzwyczajnych, został wyposażony w możliwość uzyskania informacji, jaki podmiot będzie prowadził zbiórkę, ile pieniędzy zostało zebranych i w jaki sposób rozdysponowano pieniądze i ofiary w naturze. Tym samym może zweryfikować wiarygodność i zaufanie udzielone organizatorowi zbiórki.

\section{PODSUMOWANIE}

Doskonały przykład dla wyrazistszego zilustrowania i podsumowania powyższych rozważań stanowi Komunikat z badań Centrum Badania Opinii Społecznej z czerwca 2010 r. zatytułowany Pomoc ofiarom powodzi i postulowane sposoby

${ }^{36}$ Zob. art. 10 ust. 2 ustawy o z.p.z.p. 
zwalczania jej skutków ${ }^{37}$, a przede wszystkim zaprezentowane wyniki badań przeprowadzonych w sierpniu 1997 r., w sierpniu 2001 r. (w podanym roku zadawano pytania samym poszkodowanym) oraz w czerwcu 2010 r., które polegały na udzieleniu odpowiedzi na pytanie: „W jaki sposób miał(a) Pan(i) okazję pomóc?”38. Respondenci mogli udzielić więcej niż jednej pozytywnej odpowiedzi. Wyniki przestawiały się następująco:

1) Czy dał(a) Pan(i) pieniądze w czasie zbiórki z kościele — 62\% (1997 r.); 63\% (2001 r.); 62\% (2010 r.);

2) Czy przekazał(a) Pan(i) pieniądze za pomocą SMS-a — 0\% (1997 r.); 0\% (2001 r.); 42\% (2010 r.);

3) Czy dał(a) Pan(i) pieniądze w czasie zbiórki organizowanej przez inne instytucje i organizacje - 43\% (1997 r.); 27\% (2001 r.); 31\% (2010 r.);

4) Czy przekazał(a) Pan(i) na rzecz powodzian żywność, wodę - 17\% (1997 r.); 18\% (2001 r.); 19\% (2010 r.);

5) Czy przekazał(a) Pan(i) na rzecz powodzian środki czystości - $11 \%$ (1997 r.); 15\% (2001 r.); 12\% (2010 r.);

6) Czy przekazał(a) Pan(i) na rzecz powodzian odzież, koce itp. $-20 \%$ (1997 r.); 18\% (2001 r.); 8\% (2010 r.);

7) Czy pomógł(a) Pan(i) bezpośrednio poszkodowanym - 9\% (1997 r.); $8 \%$ (2001 r.); 8\% (2010 r.);

8) Czy uczestniczył(a) Pan(i) w imprezach, z których dochód przeznaczono na pomoc dla powodzian — 9\% (1997 r.); 7\% (2001 r.); 6\% (2010 r.);

9) Czy wpłacił(a) Pan(i) pieniądze na podane konto - 8\% (1997 r.); $8 \%$ (2001 r.); 5\% (2010 r.);

10) Czy pomógł(a) Pan(i) w inny sposób - 11\% (1997 r.); 8\% (2001 r.); $10 \%$ (2010 r.).

Refleksja, która pojawia się na tle analizy podanych odpowiedzi procentowych, wskazuje, że pomoc podmiotów prywatnych udzielana jednostkom w czasie powodzi (będącej klęską żywiołowąa ${ }^{39}$, która w konsekwencji może zostać uznana za stan nadzwyczajny) wykazuje dalekie zróżnicowanie pod względem sposobów przeprowadzania tej pomocy. W okresie ponaddziesięcioletnim (lata 1997-2010) ukształtowała się tendencja wyboru zbiórek oraz zbiórek publicznych przez podmioty prywatne. Pomoc w postaci SMS-ów uzyskała poparcie społeczne dopiero w ostatnim badaniu. Wydaje się jednak, że stosunkowa wielość wysłanych SMS-ów wskazuje, że w przyszłości forma ta będzie często wybierana przez podmioty prywatne.

37 BS/91/2010, http://www.cbos.pl/SPISKOM.POL/2010/K_091_10.PDF (dalej: Komunikat).

38 Ibidem, s. 7, tab. 3.

39 Zob. art. 3 ust. 1 pkt 1 w zw. z pkt 2 ustawy o s.k.ż. 
Z oczywistych względów obecnie wyłącznie w kwestii domysłów należałoby pozostawić pytanie o wpływ nowej regulacji dotyczącej zbiórek publicznych na sposób udzielenia odpowiedzi przez respondentów.

\title{
FINANCIAL AID PROVIDED BY PRIVATE PERSONS TO ENTITIES DURING EXTRAORDINARY MEASURES
}

\begin{abstract}
Summary
In Financial Aid Provided by Private Persons to Entities during extraordinary measures, several forms of help (wire transfers, bank account deposits, charity text messages, crowdfunding) are discussed. In particular, the article is focused on public fundraising events governed under the Act on the Rules of Public Fundraising dated 14th of March 2014. The analysis also refers to the no longer binding Act on Public Fundraising Events dated 15th of March 1933. The discussion is related to the rules of public fundraising during the period of martial law and state of emergency (due to natural disaster). The article presents new public fundraising rules, especially the fundraising entity's obligation to report a fundraising event on the portal of public fundraising events.
\end{abstract}

